\title{
BATTLE OF LATERALISMS: INTELLECTUAL PROPERTY AND TRADE
}

\author{
Robert P. Merges*
}

\section{INTRODUCTION}

Like a body building contest, two rival camps in international trade policy flex their respective "lats": the multilateral camp argues for continued use of general trade agreements that apply to many countries; the bilateral camp says we must form agreements with individual countries to maximize US interests. ${ }^{1}$ Although this contest has broader dimensions, I have seen it played out on the intellectual property stage, and will comment on it from that vantage point.

It is difficult to begin discussing the "battle of the lateralisms" without reference to particulars: "Which multilateral institutions are we talking about?"; "With which countries are we considering making bilateral deals?" And, as I will conclude, whichever forum is appropriate in a given case, we must formalize the anecdotal evidence linking enhanced intellectual property protection with speedier economic development. Only this way will other countries voluntarily adopt broader intellectual property protection.

Returning to the particulars, there are two multilateral institutions: the World Intellectual Property Organization (WIPO) and the General Agreement on Tariffs and Trade (GATT). The US has negotiated bilaterally with three country groups or countries: the Newly Industrialized Countries (NICs, see Korea and Thailand), the Less Developed Countries (LDCs, which include many African nations) and Japan.

\section{MUltilateral INSTitutions}

The traditional multilateral forum is WIPO. This United Nations agency was formed to administer two important international treaties adopted in the nineteenth century: the Berne Copyright Convention and the Paris Convention (on patents). WIPO carried on its administrative functions under the treaties, and has accumulated a large staff in Geneva, a primary function of which is to spread the virtues of intellectual property to the developing world. A common complaint heard in the developed world was that WIPO had come under the sway of the LDC's, whose ideological and economic

* Professor of Law, Boston University School of Law.

1 Actually, both groups often concede the need for limited use of the other "lateralism"; the struggle centers around which approach will dominate. 
objections to increased intellectual property protection hampered WIPO's ability to implement broader protection.

As a consequence, US (and to some extent European and Japanese) industry groups began agitating to put intellectual property issues on the agenda for the Uruguay Round of GATT negotiations. Though many fail to see the relevance of these issues to the central concerns of GATT ${ }^{2}$ there was a logic to their being added to the GATT agenda. The US hoped that by introducing intellectual property issues into a forum where it had a stronger bargaining position vis-a-vis WIPO, it would have more leverage in the negotiations. From the perspective of those concerned with enhanced protection, an increasingly lethargic and bureaucratized WIPO forced these issues into GATT, relevant or not.

The problem with this new arrangement is that intellectual property is not just another trade issue. Intellectual property rights have their own history, institutional structure and constituencies; furthermore, they may involve greater conceptual complexity than many trade issues. ${ }^{3}$ Without belaboring the point, it should be noted that the very abstractness of intellectual property rights makes their administration complex. Consequently, carrying out a straightforward policy such as "strengthened rights" can require a myriad of interrelated adjustments to the principles, rules and doctrines that define the dimensions of an intellectual property right. This is more evident in the case of an initiative to broaden the scope of the claims in the average patent, for instance, than in an attempt to have pharmaceuticals included in the list of patent items in a country's patent laws. But even the latter program requires the hiring of new patent examiners and the development of pharmaceutical-specific rules and doctrines to govern what a patent applicant must disclose in her application, which new compounds deserve a patent, and which competing compounds infringe a patented compound.

Thus the content of intellectual property rights is multi-dimensional, the various rules and doctrines constituting the dimensions. Because of this, it may be difficult to adopt broad principles (such as that all inventions be "adequately" protected) that will have any effect. Thus, although the proposed TRIP Code in the Uruguay Round has some specificity to it, it may in fact suffer from the crucial flaw of vagueness.

Ironically, to enforce any such Code, the GATT might have to recreate

${ }^{2}$ Dr. Jagdish Baghwati, at the conference where this paper was delivered, referred to the Trade Relatecl Intellectual Property (TRIP) issues in the Round as "Tangentially Related Intellectual Property" issues.

3 While no one would deny the complexity of many trade issues, e.g., agricultural subsidies, it is often the assessment of impacts from rule changes that is complex. The issues themselves are not as complex as those in intellectual property. Crop subsidy programs may be complicated in some cases, but they cannot compare with the statutes and cases that answer questions such as "What is a patentable invention?"; "Is this invention new in light of everything that came before it?"; and "Is this invention a significant enough advance to warrant a patent?" 
some of WIPO's expertise, and with it some of WIPO's administrative apparatus. Though GATT may object that "intellectual property is too important to be left to the technicians," GATT may merely replace WIPO's technicians with its own. This duplication would not be total; as mentioned above, at least part of WIPO's structure is dictated by its mandate to spread the intellectual property gospel, a goal GATT would not need to undertake. But the nature of intellectual property rights, to paraphrase, is that the essence of the right is in its details. In negotiating for enhanced rights, GATT may find itself arguing over the same old "technical" rules and doctrines that WIPO has been arguing over for years. At the very least, GATT advocates should be aware that when it comes to intellectual property rights, progress requires technicians as well as strategists.

\section{BILATERAL NEgotiations}

The US has negotiated one-on-one with three country groups or countries: (1) the NICs, (2) the LDCs, and (3) Japan. The pitfalls and successes of each set of negotiations teach something about the effectiveness of bilateral dealmaking.

Perhaps the most significant progress has been made with the NIC's. In the past few years, broader intellectual property protection has been secured for American products in Korea, Hong Kong, Brazil and Thailand. Neither WIPO nor the GATT have come close to matching the deals struck with these countries. It is instructive to examine why not.

Primarily bilateral negotiations have been successful because the US is able to place intellectual property rights in a larger trade context; we can threaten vital NIC interests such as market access in a way not possible in WIPO, which is concerned only with intellectual property rights. There is little potential for horsetrading in the WIPO context. Even when a US negotiator (in WIPO) can fashion a deal, s/he must face the LDC majority, making it most unlikely that anything substantially beneficial to the US will be passed.

Typically, smaller but politically connected "pirate" industry groups dominate debate over alterations of patent and copyright statutes. Bilateral negotiations urging NICs to alter their internal statutes can potentially benefit from political dynamics within NICs. By proposing foreign economic policy beneficial to NICs contingent on stronger NIC protection of intellectual property rights, the US can draw NIC manufacturing and trading companies into the debate. This seems to have been successful in the case of Korea.

Results have been less successful with respect to LDCs. Many LDCs continue to resist the expansion of patent protection. For the most part the lack of progress has not greatly exercised the US, due to the small markets most LDCs represent. The lesson is that in these countries bilateral negotiating is not worth the price. This suggests a need for multilateral forums such as 
WIPO, to allow nations to negotiate intellectual property matters without the expense of dealing with LDCs individually.

Japan is a special case. Although cooperation between the US and Japanese Patent Offices goes back many years, recent publicity has put many features of the Japanese patent system in public view, and hence on the agenda of trade negotiators. The Japanese patent system is often used as an example of non-tariff barriers employed by Japan. US-Japanese intellectual property negotiations are complicated by the complexities of the legal issues involved. Progress, as defined by the US side, will require more than detailed rule changes. The Japanese patent system has been said to limit the scope of exclusive rights which can be obtained, and thus encourage minimal claiming, licensing, and other "cooperative" behaviors. There is some truth to this claim. If correct, it marks a stark contrast with the more individualistic, pioneer-oriented US system. To that extent, the patent systems reflect deep-seated cultural differences.

A cynic might then observe that negotiating patent changes between the US and Japan is like a Jesuit arguing with an atheist over the nature of God. A more pragmatic view of the negotiations would emphasize the importance to the US of obtaining concessions on the details of Japanese patent practice. US firms would benefit by Japanese concessions regarding, among other things, the breadth of claims permissible in applications, the scope of claims for infringement purposes, and limits to the opposition procedures available to challengers of an application.

The three sets of negotiations just described illustrate the strengths of bilateralism. Because different countries are at different stages of development at any one time, multilateral codes can only operate at fairly high levels of generality. The Paris Convention on patent law is an example. It establishes important principles, yet leaves much room for variation in the patent laws of member countries. The proposed GATT intellectual property code, which attempts to provide more substantive guidelines, has met with stiff opposition from some members of the Paris Convention, in part because of its specificity on certain matters (e.g., pharmaceutical patents). Individual countries believe they would feel the effects of the proposed code's specific provisions in different ways. Those which see net economic harm resist the code. Bilateralism allows a way out of this impasse. Agreements can be tailored to specific countries, and maximum gains can be negotiated across a variety of countries.

But there is a cost. Few negotiators have the expertise to carry on negotiations with individual countries. There may be a surplus of trade negotiators, but there is a deficit of international patent experts. Though this may argue for multilateralism, the shortfalls of the multilateral approach outlined above still apply. There remains a place for multilateralism, but the limitations of the available forums counsel caution. They may be more efficient, but that does not make them effective. Ultimately, bilateralism should be expected to predominate. The various agencies, especially the United States 
Trade Representative (USTR) and the Patent Office, will have to set priorities for allocating their bilateral negotiating resources.

\section{CONVINCING OTHER COUNTRIES TO EXPAND INTELleCtuAL Property Protection}

Whichever forum is chosen, US negotiators must convince their counterparts to adopt broader intellectual property protection. Such persuasion takes two forms: threats and promises. Section 301 provisions on intellectual property are an example of the former, while other tactics used in recent negotiations are instances of the latter.

Threats have been shown effective with regard to Korea. Promises usually take the form of statements that the evidence shows that stronger intellectual property protection will be a net benefit to the reluctant country's domestic economy.

In 1988 the International Trade Commission prepared an estimate of the loss to US firms from violations of intellectual property rights (ITC Study). ${ }^{4}$ The range of estimated losses was $\$ 43$ billion to $\$ 61$ billion per year. Though based on estimates, these figures provide the starting point for the US negotiating position.

To sell broader protection to the LDCs and NICs, economists have been enlisted to estimate the impact of changes in intellectual property laws on their. A recent study approached the problem by asking how much extra annual growth it would take in various LDC/NIC economies to offset the loss of revenues from industries dependent on weak intellectual property protection (pirate industries). The estimates - stretched over a twenty-five year time horizon - ranged from $.07 \%$ for India and Mexico to $.2 \%$ for Argentina. ${ }^{5}$ The US would argue that much of this growth will be supplied by new investment spurred by broader intellectual property rights.

Estimates of GNP growth in NICs and LDCs as a consequence of broader intellectual property protection in studies designed for advocacy should ultimately be examined for biases in their assumptions. But this paper will simply ask why, if it is in these countries' interests to change their laws, they don't.

An answer which does not undermine the "self-interest" arguments for change comes from the literature on "public choice," or collective action theory. ${ }^{6}$ This framework would explain the reluctance to change intellectual property regimes by reference to well-entrenched interest groups. Though it might be in the best interests of a country as a whole to change, representa-

4 U.S. INT'L Trade Comm'N., Foreign Protection of INTEllectual Property Rights AND the EFfect ON U.S. INDUSTRY AND TRAdE, ITC Pub. No. 2065 (Feb. 1988).

5 M. Gadbaw, Protecting Intellectual Property Rughts Worldwide 107 (1988).

6 See M. Olson, The Logic of Collective Action: Public Goods and the THEORY OF GROUPS (1965) (a general discussion of collective action theory). 
tives of the "pirate" industries may have enough political clout to block the proposed changes. As mentioned, one feature of bilateral negotiations is that they have the potential to break the stranglehold of special pirate interests on foreign legislative bodies. By placing larger interests of the nation at risk in the negotiations, these negotiations invite participation from larger economic players who can offset the political influence of the entrenched pirate groups. But another answer is possible. Some countries might be better off not broadening protection. There is no reason to assume that pirate industries are overrepresented in the legislative processes of all countries that oppose broadened rights. And there is no reason to assume that all countries would compensate with growth for the loss due to the elimination of pirate industries. There are those in the NIC/LDC community who believe so:

Practically all the patents in the Third World are foreign- owned. As such, the monopoly privileges granted through patents have, among other repercussions, an international rather than simply a domestic, income distribution effect. They also have, as a result of income flows across national boundries, balance of payments implications. . . . ${ }^{7}$ Data on balance of payments supports at least part of this position. ${ }^{8}$

Key to understanding the NIC/LDC position is to recognize that to these countries, intellectual property is primarily a matter of technology transfer, rather than of encouragement of innovation. ${ }^{9}$ Their goal is to maximize technology imports given a low transfer payment budget. For countries seeking inflow of technological information, any loss of GNP growth works contrary to their goals. And they are naturally inclined to ask whether the studies on estinaated GNP loss impartially account for all the costs of increased protection.

US negotiators might place greater emphasis on technology transfer issues. The US should stress that stronger protection would increase imports, patent application filings, and licensing activity, all of which contribute to inflow of technology. It is clear that much technological information cannot be learned from studying foreign products and patents; personto-person communication of the details of how things work is equally important. ${ }^{10}$ As such communication often takes place in the context of licensor-

7 Vaitsos, Legal Issues in the Revision of the International Patent System, in THE Political ECONOMY OF LAw: A THIRD World READER 304, 305 (Y. Ghai, R. Luckham \& F. Snyder eds., 1987).

8 U.S. DePT. OF COMM., U.S. DiReCt INVESTMENT ABROAD: 1982 BenchmaRK SURVEY DATA (Dec. 1985) (U.S. ran a positive net balance of payments for intellectual property licensing royalties of $\$ 4.4-4.5$ billion in 1982-1984).

9 Science AND Technology: Lessons for Development Policy 353 (R. Evenson \& G. Ranis eds., 1990) (while adoption of current international intellectual property conventions by developing countries might be globally optimal, it is not in the best interests of particular developing countries, since the best regime for them is one that facilitates the transfer of technology).

10 See e.g., Contractor, Technology Importation Policies in Developing Countries: Some 
licensee relations, and since these relations are based on underlying intellectual property rights, the symbiosis between know-how training and intellectual property should be stressed. This information may not be fully appreciated in the LDC/NIC world, perhaps explaining why these countries perceive it in their self-interest to oppose broader protection.

Nonetheless, broader protection may not make sense for all countries. A recent issue of The Economist observed:

Companies in rich countries often imply that all such diputes over intellectual property are a straightforward matter of piracy or theft. . . . However, the developing countries are more concerned about patent protection for technologically sophisticated goods such as drugs and chemical fertilizers. . . . In many cases, matching rich-country standards of patent protection would make such goods a lot more expensive to thrid-world buyers. ... [I]n their dealings with the third world, companies regard the conventions agreed at home as self-evidently correct for everywhere else. It is not at all obvious that the developing countries are obliged, either morally of for the sake of sound economics, to meet the rich countries' demands. ${ }^{11}$

The history of the United States bears this out. Until sometime in the nineteenth century the US was a net technology importer; some technology was obtained despite foreign intellectual property-type claims. For example, in the early days of steam engine technology, Britain forbade the export of engines, parts, and skilled personnel. The US imported all three regardless. ${ }^{12}$ Recognition of British rights might have yielded a net benefit to the US, but that is doubtful. The decision was made in the US that at that stage of economic development, the best policy for the US was lax enforcement of foreign intellectual property. Can the US now say that all developed countries are in such different positions that they cannot make the same decision?

Implications of Recent Theoretical and Empirical Evidence, 17 J. DEVELOPING AREAS 499, 505 (1983). But see Kirim, Reconsidering Patents and Economic Development: A Case Study of the Turkish Pharmaceutical Industry, 13 WoRLD DEv. 219, 232 (1985) (patents have no straightforward relationship to transfer of technology; they neither help nor hurt).

11 Something Old, Something New, Special Survey on World Trade, THE EconomisT, Sept. 22, 1990, at 34, 35 .

12 David Jeremy, Penetrating British Barriers to Technology Transfer in the Early Industrial Period, 1790s-1840s: Some Recent Research, Paper presented at the Society for the History of Technology Annual Conference, Sacramento California, Oct. 1989, at 6-12 (prohibitory export laws in Britain were easily evaded by exporting only mental images of the technology rather than physical embodiments); see generally D. JEREMY, Transatlantic Industrial Revolution: The Diffusion of Textile Technologies Between BRTtaIN AND AMERICA, 1790-1830s (1981) (an in-depth study of how American firms evaded British restrictions on technology export, especially emigration of skilled workers, and thereby built the U.S. textile industry into world power). 
That is not to say that lax protection does not impede economic development in some countries. A recording industry flourished in Hong Kong for the first time after passage of a copyright act protecting sound recordings; the Indian software industry saw a growth surge after a copyright was extended to software; and so on. A recent study of business practices in Brazil and Mexico provides fascinating details of the business losses which result from inadequate protection, especially regarding recruitment of employees with knowledge of trade secrets. ${ }^{13}$ Note that all these countries are relatively advanced, however; perhaps stronger rights make sense at some "takeoff" stage in a country's development.

\section{CONCLUSION}

It is difficult in practice to determine which countries would actually benefit from strengthened intellectual property rights. ${ }^{14}$ But clearly, a monolithic "stronger rights" approach will not work. Unless enough country-by-country flexibility can be built into a multilateral framework, bilateralism may be the best solution.

In the meantime, the US must highlight the positive domestic consequences of enhanced protection in those countries which objective research shows would truly benefit from it. To shore up the US position in this respect, the US needs credible economic data on the Hong Kong and India anecdotes mentioned above. Additionally, if a free trade agreement with Mexico goes forward, intellectual property might be made a part of it. The effects of stronger protection on a NIC economy which is both familiar and easily accessible to study could then be assessed. Only be collecting persuasive data can the US hope to convince other NICs/LDCs to change their intellectual property regimes. Where the data shows no real improvement in the domestic economy from stronger protection, the US must live with the fact that pressure for change will most likely be unavailing.

13 See R. Sherinood, Intellectual Property and Economic Development 101-58 (1989).

14 Frame, National Commitment to Intellectual Property Protection: An Empirical Investigation, 2 J. L. \& TECH. 209, 217-18 (1987) (the countries with the weakest protections are those on the verge of emerging into developed world). 